\title{
BIOLOGY AND FISHERY OF THE ARCHED BOX CRAB Calappa convexa DE SAUSSURE (CRUSTACEA, BRACHYURA, CALAPPIDAE) IN THE SOUTHEASTERN GULF OF CALIFORNIA, MEXICO
}

\section{BIOLOGÍA Y PESQUERÍA DEL CANGREJO CAJETA BOLA Calappa convexa DE SAUSSURE (CRUSTACEA, BRACHYURA, CALAPPIDAE) EN EL SURESTE DEL GOLFO DE CALIFORNIA, MÉXICO}

\author{
Manuel Ayón-Parente \\ Michel E. Hendrickx \\ Instituto de Ciencias del Mar y Limnología \\ Unidad Académica Mazatlán, \\ Universidad Nacional Autónoma de México \\ P.O. Box 811 \\ Mazatlán 82000, Sinaloa, Mexico \\ e-mail: manuel@ola.icmyl.unam.mx \\ michel@mar.icmyl.unam.mx
}

Recibido en enero de 2001; aceptado en septiembre de 2001

\begin{abstract}
The arched box crab (Calappa convexa) is commonly caught in gillnets as by-catch of the spiny lobster (Panulirus spp.) fishery in southern Sinaloa, Mexico, a locally exploited fishing resource. Crabs were sampled monthly from May 1998 to April 1999 and a total of 274 specimens (132 males and 142 females) were captured. The distribution of the resource was homogeneous (present in $72 \%$ of the samples) throughout the sampling area. The overall sex ratio (female:male) was 1:0.92 $\left(\chi^{2}>0.05\right)$. The capture per unit effort (CPUE) varied from $0.81 \mathrm{~g} / 100 \mathrm{~m}^{2} / \mathrm{h}$ to $9.10 \mathrm{~g} / 100 \mathrm{~m}^{2} / \mathrm{h}$. Maximum catch was obtained in June while minimum catches occurred in December and March. The CPUE values differed significantly (ANOVA $P<0.05$ ) among the months of sampling. Crabs were caught on sand, rock and boulders, with $43 \%$ of the CPUE corresponding to rocky substrate. Mean size, based on carapace length (CL), was $72.5 \pm 5.8 \mathrm{~mm}$ for males and $74.5 \pm 7.2 \mathrm{~mm}$ for females. Individual size frequency distribution was unimodal and normal in males and unimodal and not normal in females, with the largest number occurring in spring (107) and winter (73). Reproduction occurred throughout the year, with peaks from April to August. Females reached sexual maturity at an estimated size of $75 \mathrm{~mm}$ (CL-50) and carried an average of 638,885 eggs. The mean size differed significantly between females $(75.7 \mathrm{~mm} \mathrm{CL}$, $\mathrm{SD}=7.3 \mathrm{~mm})$ and males $(72.8 \mathrm{~mm} \mathrm{CL}, \mathrm{SD}=5.8 \mathrm{~mm})(P<0.05)$. The modal classes displayed a slight seasonal displacement (spring to winter) towards larger sizes. Analysis of the carapace width:length relationship shows variation during male and female development, specifically, in larger sizes (> $75 \mathrm{~mm} \mathrm{CL}$ ), females were narrower while the opposite occurred in males. Left and right chelae reached a combined fresh weight of $100 \mathrm{~g}$, in males of about $75.0 \mathrm{~mm} \mathrm{CL}$, while in females this weight was reached at $79.0 \mathrm{~mm}$ CL.
\end{abstract}

Key words: Calappa convexa, spiny lobster by-catch, abundance, distribution, biology. 
Ciencias Marinas, Vol. 27, No. 4, 2001

\section{RESUMEN}

El cangrejo cajeta bola (Calappa convexa) es capturado comúnmente en las redes de enmalle como parte de la fauna de acompañamiento de la langosta espinosa (Panulirus spp.) en el sureste de Sinaloa, México, constituyendo un recurso pesquero explotado localmente. Se recolectaron muestras de cangrejos cada mes durante el período de mayo de 1998 a abril de 1999 y se obtuvieron 274 especímenes (132 machos y 142 hembras). La distribución del recurso fue homogénea (presente en $72 \%$ de las muestras) a lo largo del área de muestreo. La proporción entre sexos (hembra:macho) fue 1:0.92 $\left(\chi^{2}>0.05\right)$. La captura por unidad de esfuerzo (CPUE) varió de $0.81 \mathrm{~g} / 100 \mathrm{~m}^{2} / \mathrm{h}$ a $9.10 \mathrm{~g} / 100 \mathrm{~m}^{2} / \mathrm{h}$. La captura máxima fue obtenida en junio y las mínimas ocurrieron en diciembre y marzo. Los valores de CPUE difirieron significativamente (ANOVA $P<0.05$ ) entre los meses de muestreo. Los cangrejos fueron capturados en sustratos arenoso, rocoso y de cantos rodados. El 43\% de la CPUE correspondió a sustratos rocosos. La talla media, basada en la longitud del caparazón (CL), fue de $72.5 \pm 5.8 \mathrm{~mm}$ para los machos y de $74.5 \pm 7.2 \mathrm{~mm}$ para las hembras. La distribución de frecuencias de las tallas fue unimodal y normal en los machos y unimodal y no normal en las hembras, con las mayores frecuencias en la primavera (107) y el invierno (73). La especie se reproduce a lo largo del año con picos máximos entre abril y agosto. La talla media de madurez sexual en las hembras fue de $75 \mathrm{~mm}$ (CL-50), llevando un promedio de 638,885 huevecillos. La talla media difirió significativamente entre las hembras $(75.7 \mathrm{~mm} \mathrm{CL}, \mathrm{SD}=7.3 \mathrm{~mm})$ y los machos $(72.8 \mathrm{~mm} \mathrm{CL}, \mathrm{SD}=5.8 \mathrm{~mm})(P<0.05)$. Las clases modales mostraron un ligero desplazamiento estacional (de la primavera al invierno) hacia las tallas grandes. El análisis de la relación ancho:longitud de caparazón permitió detectar una variación durante el desarrollo de los machos y de las hembras. En particular, en las tallas mas grandes ( $>75 \mathrm{~mm} \mathrm{CL})$, las hembras fueron más angostas mientras que con los machos ocurrió lo contrario. Las quelas izquierda y derecha alcanzaron, en los machos, un peso en fresco combinado de $100 \mathrm{~g}$, el cual es alcanzado en tallas cercanas a los $75.0 \mathrm{~mm} \mathrm{CL}$, mientras que en las hembras este peso es alcanzado a los $79.0 \mathrm{~mm}$ CL.

Palabras clave: Calappa convexa, fauna de acompañamiento de langosta espinosa, abundancia, distribución, biología.

\section{INTRODUCTION}

Population studies of marine species in limited areas provide information that increases the understanding of the population dynamics in larger areas. It is essential that fishery policies were based on reliable harvesting data and biological information of the subject species obtained within the context of conservation and sustainable use in marine and coastal research. However, such data often do not exist. Surveys and inventories of natural resources are now recognized as basic tools for reinforcing or directing sustainable exploitation, particularly in poorly known areas of the tropics (McNeely, 1990; UNEP, 1997). In these areas, basic

\section{INTRODUCCIÓN}

El estudio de poblaciones de especies marinas en áreas limitadas proveen información que puede aplicarse a nuestro conocimiento de su dinámica de población en áreas más grandes. Es esencial que las políticas en el manejo de las pesquerías se establezcan en base a información biológica y datos de captura confiables de las especies de interés, obtenidos en el contexto de la conservación y el uso sustentable de los recursos bióticos de las zonas marinas y costeras. Sin embargo, esta información a menudo no existe. Los estudios e inventarios de los recursos naturales son actualmente reconocidos como una herramienta básica para reforzar $\mathrm{u}$ 
Ayón-Parente and Hendrickx: Biology and Fishery of Calappa convexa in the Gulf of California

information is still needed in order to define which species are over-exploited and to evaluate the damage caused to natural ecosystems (Hatcher et al., 1989; Thorpe et al., 1995).

In southern Sinaloa, approximately 350 species of decapod crustaceans are found, accounting for approximately $66 \%$ of all species known for the Gulf of California (Hendrickx, 1993, 1996). Many of these species are not exploited although they often represent an important fishery potential (Hendrickx, 1985, 1995a). Box crabs (family Calappidae s.1.) are represented in the eastern Pacific by 15 species (Hendrickx, 1995a). The largest species belong to the genera Hepatus (H. lineatus Rathbun, 1898) and Calappa (C. convexa de Saussure, 1853). Previous studies on C. convexa consist of morphological descriptions, ecological data and reports about its geographic distribution (e.g., Rathbun, 1937; Garth, 1946, 1948, 1966; von Prahl and Sánchez, 1986; Hendrickx 1995b, 1997). This species occurs from Magdalena Bay, on the west coast of the Baja California Peninsula and from Punta Peñasco, Sonora, in the northern Gulf of California, Mexico, to Tumbes, Peru, including the Galapagos Islands. It is found in coastal waters from the intertidal zone to a depth of $75 \mathrm{~m}$ and has been recorded on muddy, muddy-sand, sandy, sandy-mud and rocky substrates (Garth, 1948; Sosa-Hernandez et al., 1980; Hendrickx, 1995b, 1997). Most available information has been obtained from commercial or experimental trawls on the continental shelf. Consequently, the biological and ecological data from the shallow water fringe $(0-10 \mathrm{~m})$ where this species is known to occur are scarce. The fishery potential for the arched box crab in coastal waters off the Gulf of California, and in particular, in southern Sinaloa, has been reported by several authors, who have observed the species as part of the by-catch of shrimp (Penaeidae) (Hendrickx, 1985, 1995b; Rodríguez de la Cruz, 1987) orientar los mecanismos de explotación sustentable, particularmente en las áreas tropicales poco conocidas (McNeely, 1990; UNEP, 1997). En estas áreas aún es necesaria información básica para poder definir cuales especies están siendo sobreexplotadas y evaluar el daño causado a los ecosistemas naturales (Hatcher et al., 1989; Thorpe et al., 1995).

En el sur de Sinaloa se encuentran aproximadamente 350 especies de crustáceos decápodos, correspondientes al $66 \%$ de todas las especies conocidas para el Golfo de California (Hendrickx, 1993, 1996). La mayoría de estas especies no son explotadas a pesar de que representan un potencial pesquero importante (Hendrickx, 1985, 1995a). Los cangrejos cajeta bola (familia Calappidae s.1.) están representados en el Pacífico oriental por 15 especies (Hendrickx, 1995a). Las especies más grandes corresponden a los géneros Hepatus ( $H$. lineatus Rathbun, 1898) y Calappa (C. convexa de Saussure, 1853). Los estudios previos realizados acerca de $C$. convexa se refieren a su descripción morfológica, a datos ecológicos y a registros de distribución geográfica (e.g., Rathbun, 1937; Garth, 1946; 1948; 1966; von Prahl y Sánchez, 1986; Hendrickx 1995b, 1997). Esta especie se distribuye desde Bahía Magdalena, en la costa occidental de la Península de Baja California, y de Punta Peñasco, Sonora, en el norte del Golfo de California, México, hasta Tumbes, Perú, incluyendo las Islas Galápagos. Se encuentra en aguas costeras desde la zona intermareal hasta profundidades de $75 \mathrm{~m}$ y ha sido registrada en sustratos lodosos, lodo-arenosos, arenosos, areno-lodosos y rocosos (Garth, 1948; Sosa-Hernández et al., 1980; Hendrickx, 1995b, 1997). La mayor información disponible ha sido obtenida durante arrastres experimentales o comerciales en la plataforma continental. Consecuentemente, la información biológica y ecológica en la franja de aguas someras $(0-10 \mathrm{~m})$ es escasa. El potencial pesquero para el cangrejo cajeta 
or, more recently, of the spiny-lobster (Panulirus spp.) fishery when gillnets are used (Lim-Cisneros and Chavira-Oropeza, 1995; Hendrickx and Ayón-Parente, 1996; AyónParente, 1997). Although, there is no organized market for this species along the Pacific coast of Mexico, it is often used at subsistence level by fishermen who harvest the claws, returning the mutilated or dead organisms to the sea. In Ecuador, specimens of the arched box crab area available at the local market at 0.40 US dollars each. Claws are also sold separately for local consumption (Motoh, 1997). The crab is also sold fresh in local markets in Colombia (Hendrickx, 1995b).

Although Calappidae has been intensively studied along the east coast of America (Hebling et al., 1994; Reigada et al., 1994; Medina-Mantelatto and Petracco, 1997), there are no available data related to the biology and the fishery potential for this family of crabs along the east Pacific. The aim of this study is to provide biological and distributional data of the local shallow water population of the arched box crab $C$. convexa in southern Sinaloa, based on the by-catch of the gillnet spiny lobster fishery.

\section{MATERIALS AND METHODS}

The study area is located at the northernmost edge of the tropical belt, just south of the Tropic of Cancer, in the southeastern part of the Gulf of California (fig. 1). The coastline is characterized by long sandy beaches interrupted occasionally by rocky points, the mouth of the Quelite River, and the Bay of Mazatlan. The latter is considered one of the richest natural ecosystems in the southern Gulf of California (Hendrickx, 1993).

Specimens were sampled once or twice a week from May 1998 to April 1999. A total of 68 field trips were made, and 207 samples of spiny-lobster by-catch were obtained from 10 bola en las aguas costeras del Golfo de California y, en particular en el sur de Sinaloa, ha sido reportado por varios autores, quienes han observado la especie como parte de la fauna de acompañamiento del camarón (Penaeidae) (Hendrickx, 1985, 1995b; Rodríguez de la Cruz, 1987) o, más recientemente, de la langosta espinosa (Panulirus spp.) cuando se utilizan redes de enmalle (Lim-Cisneros y ChaviraOropeza, 1995; Hendrickx y Ayón-Parente, 1996; Ayón-Parente, 1997). A pesar de que no existe un mercado organizado para la especie a lo largo de la costa del Pacífico mexicano, a menudo es utilizada a nivel de subsistencia por los pescadores que recolectan las quelas y regresan los organismos mutilados o muertos al mar. En Ecuador, los especímenes del cangrejo cajeta bola alcanzan en el mercado local un precio de 0.40 dólares de los EUA. Las quelas también son vendidas por separado para consumo local (Motoh, 1997). Este cangrejo también es vendido fresco en los mercados locales en Colombia (Hendrickx, 1995b).

A pesar de que los Calappidae han sido intensamente estudiados a lo largo de la costa este de América (Hebling et al., 1994; Reigada et al., 1994; Medina-Mantelatto y Petracco, 1997), no existe información disponible sobre la biología y el potencial pesquero de esta familia de cangrejos para la costa del Pacífico oriental. El propósito de este estudio es proveer información biológica y de distribución de la población de aguas someras de $C$. convexa en el sur de Sinaloa, basada en la fauna de acompañamiento de la pesquería de langosta espinosa con redes de enmalle.

\section{MATERIALES Y MÉTODOS}

El área de estudio se encuentra situada en el margen septentrional del cinturón tropical, justo al sur del Trópico de Cáncer, en el sureste del Golfo de California (fig. 1). La línea de costa se caracteriza por sus largas playas 


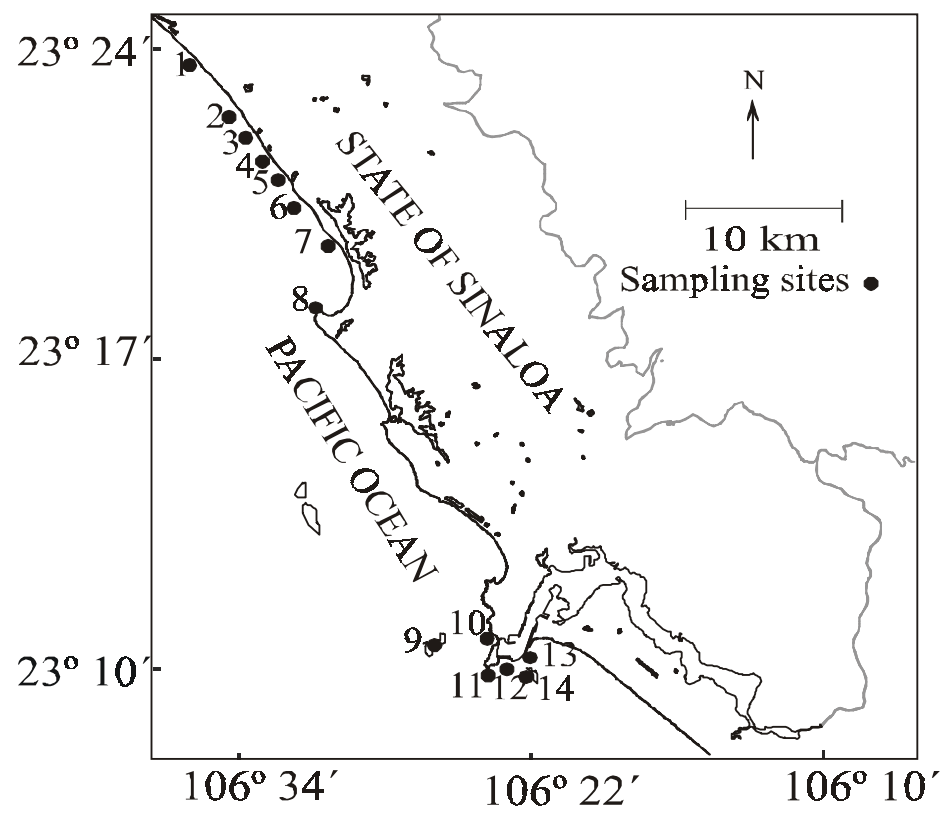

Figure 1. Location of sampling localities along the coast of Sinaloa, SE Gulf of California, Mexico. Figura 1. Ubicación de las localidades de muestreo en la costa de Sinaloa, SE del Golfo de California, México.

sites located along the coast of southern Sinaloa (fig. 1). The samples were obtained from the spiny-lobster fishermen immediately after the gillnets were retrieved. The fishermen set their gillnets overnight using small motor boats. The gillnets have mesh sizes from 10 to $12.5 \mathrm{~cm}$ (4 to 5 inches), an average length of $80 \mathrm{~m}$ and are 1.20 -m-high $\left(100 \mathrm{~m}^{2}\right.$ total surface). The specimens of $C$. convexa were separated from the rest of the by-catch and kept in sea water containers. The type of substrate (sand, rock or boulders) and the depth were recorded at each sample location. In the laboratory, crabs were sexed and carapace width and length (CW and CL, respectively) were measured to the nearest $0.1 \mathrm{~mm}$. Regression analyses were used to define the relationship between $\mathrm{CL}$ and $\mathrm{CW}$. Frequency analyses were based on 5-mm size classes. Each month, some females were selected randomly and dissected arenosas, interrumpidas ocasionalmente por puntas rocosas, la desembocadura del Río Quelite y la Bahía de Mazatlán. Esta última localidad es considerada como uno de los ecosistemas naturales más ricos del sur del Golfo de California (Hendrickx, 1993).

Los especímenes fueron muestreados una o dos veces por semana, de mayo de 1998 a abril de 1999. Se realizaron un total de 68 salidas al campo y se obtuvieron 207 muestras de la fauna de acompañamiento de la langosta espinosa de 10 sitios localizados a lo largo de la costa del sur de Sinaloa (fig. 1). Las muestras se obtuvieron de los pescadores de langosta inmediatamente después de que las redes de enmalle fueron recobradas. Los pescadores tienden las redes durante la noche utilizando pequeñas embarcaciones de motor. Las redes de enmalle tienen una luz de malla de 10 a $12.5 \mathrm{~cm}$ (4 a 5 pulgadas) y miden en promedio 
to determine the size at first sexual maturity based on the gonad color scale used by Caldwell (1992).

In order to determine the size:weight relationships, whole crabs and chelipeds (first pereiopod) were weighed separately on an electronic balance to the nearest $0.1 \mathrm{~g}$, being $\mathrm{Wt}$ the total crab fresh weight while Wp was the combined fresh weight of left and right chelipeds $\left(\mathrm{Wt}=a \mathrm{CL}^{b} ; \mathrm{Wp}=c \mathrm{CL}^{d}\right)$. The condition factor was defined by the value of $a$ and the allometry coefficient was defined by the value of $b$ (Ricker, 1975). The relative abundance of the species was expressed as fresh weight $(\mathrm{g})$ per gillnet area $\left(100 \mathrm{~m}^{2}\right)$ per hour, or catch per unit effort (CPUE, $g / 100 \mathrm{~m}^{2} / \mathrm{h}$ ). An analysis of variance (ANOVA) was used to test differences among sampling localities, monthly catches and between catches and substrate types. A multiple comparison test (Duncan) was used to test significant variation in the ANOVA. A $\chi^{2}$ test was used to determine heterogeneity in the sex ratio, which was expressed as F:M (number of females related to number of males). A Student's test was used to compare the slopes of the CL:CW relationships between females and males.

\section{RESULTS}

\section{Distribution and relative abundance}

Specimens of $C$. convexa were obtained in 49 out of the 68 samples $(72 \%)$. Specimens were caught at 12 of the 14 sampling sites. Stations 4 and 12 were visited just once and no specimen of $C$. convexa was caught (table 1). Overall average catch was about four specimens per sample. The difference in catches per locality was not significant considering the sampling frequency and the number of specimens obtained. No spatial segregation was detected by sex $\left(\chi^{2}>0.05\right)$, but the comparison of the average size of the specimens collected
$80 \mathrm{~m}$ de longitud por $1.20 \mathrm{~m}$ de caída $\left(100 \mathrm{~m}^{2}\right.$ de área total). Los especímenes de $C$. convexa fueron separados del resto de la fauna de acompañamiento y colocados en contenedores con agua de mar. En cada localidad de muestreo se registró el tipo de sustrato (arena, roca o cantos rodados) y la profundidad. En el laboratorio, los cangrejos fueron sexados y se obtuvieron, con una precisión de $0.1 \mathrm{~mm}$, las medidas del ancho y la longitud del caparazón (CW y CL, respectivamente). Se utilizaron análisis de regresión para definir la relación entre CL y CW. Los análisis de frecuencia se basaron en intervalos de clase de $5 \mathrm{~mm}$. Cada mes, se seleccionaron al azar algunas hembras que fueron disectadas para determinar la talla de la primera madurez sexual en base a la escala de coloración de las gónadas utilizada por Caldwell (1992). El cangrejo completo y los quelípedos (primer pereiópodo) fueron pesados por separado, siendo Wt el peso en fresco total del organismo, mientras que $\mathrm{Wp}$ es el peso en fresco combinado de los quelípedos izquierdo y derecho. El pesaje se realizó en una balanza electrónica con una precisión de $0.1 \mathrm{~g}$ para determinar la relación talla-peso $\left(\mathrm{Wt}=a \mathrm{CL}^{b}\right.$; $\left.\mathrm{Wp}=c \mathrm{CL}^{d}\right)$. El factor de condición fue definido por el valor de $a$ y el coeficiente de alometría por el valor de $b$ (Ricker, 1975). La abundancia relativa de la especie fue expresada como el peso en fresco (g) por área de red de enmalle $\left(100 \mathrm{~m}^{2}\right)$ por hora, o captura por unidad de esfuerzo (CPUE, g/ $100 \mathrm{~m}^{2} / \mathrm{h}$ ). Se utilizó el método de análisis de varianza (ANOVA) para probar diferencias entre las localidades de muestreo, las capturas mensuales y entre las capturas y el tipo de sustrato. Para comprobar la significancia de la variación en el ANOVA se utilizó una prueba de comparación múltiple (Duncan) y una prueba $\chi^{2}$ para determinar la heterogeneidad en la proporción de sexos. La proporción de sexos se expresó como F:M (número de hembras en relación con el número de machos). Se usó una prueba de Student para 
Table 1. Frequency of occurrence (number of samples with specimens $v s$. total number of samples at a given locality) of Calappa convexa in the 14 sampling locations, number of specimens captured (by sex: $\mathrm{M}=$ males; $\mathrm{F}=$ females), average size (CL, $\mathrm{mm})$ and $\mathrm{SD}$.

Tabla 1. Frecuencia de ocurrencia (número de muestras con especímenes $v s$. número total de muestras en cada localidad) de Calappa convexa en las 14 localidades de muestreo, número de especímenes capturados (por sexo: $\mathrm{M}=$ machos; $\mathrm{F}=$ hembras), talla media (CL, mm) y SD.

\begin{tabular}{ccccc}
\hline Sampling locality & Frequency (\%) & Specimens number & Average size $(\mathrm{mm})$ & SD \\
\hline 1 & $1 / 1(100)$ & $5 \mathrm{M}, 9 \mathrm{~F}$ & 74.3 & 8.2 \\
2 & $2 / 4(50)$ & $4 \mathrm{M}, 2 \mathrm{~F}$ & 74.0 & 5.1 \\
3 & $9 / 9(100)$ & $27 \mathrm{M}, 25 \mathrm{~F}$ & 72.2 & 6.4 \\
4 & $0 / 1(-)$ & - & - & 5.7 \\
5 & $9 / 11(82)$ & $28 \mathrm{M}, 28 \mathrm{~F}$ & 73.3 & 7.0 \\
6 & $2 / 2(100)$ & $6 \mathrm{M}, 3 \mathrm{~F}$ & 73.7 & 4.4 \\
7 & $3 / 5(60)$ & $9 \mathrm{M}, 9 \mathrm{~F}$ & 74.8 & 2.7 \\
8 & $1 / 1(100)$ & $2 \mathrm{M}, 1 \mathrm{~F}$ & 69.8 & 5.1 \\
9 & $2 / 5(40)$ & $3 \mathrm{M}, 3 \mathrm{~F}$ & 75.6 & 6.5 \\
10 & $3 / 7(43)$ & $8 \mathrm{M}, 6 \mathrm{~F}$ & 70.9 & 8.4 \\
11 & $6 / 7(86)$ & $13 \mathrm{M}, 11 \mathrm{~F}$ & 74.2 & - \\
12 & $0 / 1(-)$ & - & - & 9.7 \\
13 & $5 / 7(71)$ & $11 \mathrm{M}, 28 \mathrm{~F}$ & 76.7 & 6.1 \\
\hline 14 & $6 / 7(86)$ & $15 \mathrm{M}, 18 \mathrm{~F}$ & 77.0 & \\
\hline
\end{tabular}

indicates a significant difference between sampling stations 8, 13 and 14 (Duncan test on $S^{2}$, $P<0.005)$.

A total of 274 specimens (132 males and 142 females) of $C$. convexa were captured. The number of crabs obtained monthly varied from 6 to 57 organisms, with no captures in November due to technical problems (fig. 2a). Considering all the specimens, the mean individual weight varied from $75.6 \mathrm{~g}$ in June to $101.4 \mathrm{~g}$ in January, while the mean individual size varied from $71.4 \mathrm{~mm}$ in March to $76.3 \mathrm{~mm}$ in December (fig. 2b, c). The mean size of the specimens comparar las pendientes de la relación CL:CW entre hembras y machos.

\section{RESULTADOS}

\section{Distribución y abundancia relativa}

Se efecturaron 68 muestreos y, en 49 de ellos (72\%), se obtuvieron especímenes de $C$. convexa. Se capturaron especímenes en 12 de las 14 localidades de muestreo; las estaciones 4 y 12 fueron visitadas una sola vez y, en ellas, no se capturaron especímenes de $C$. convexa 

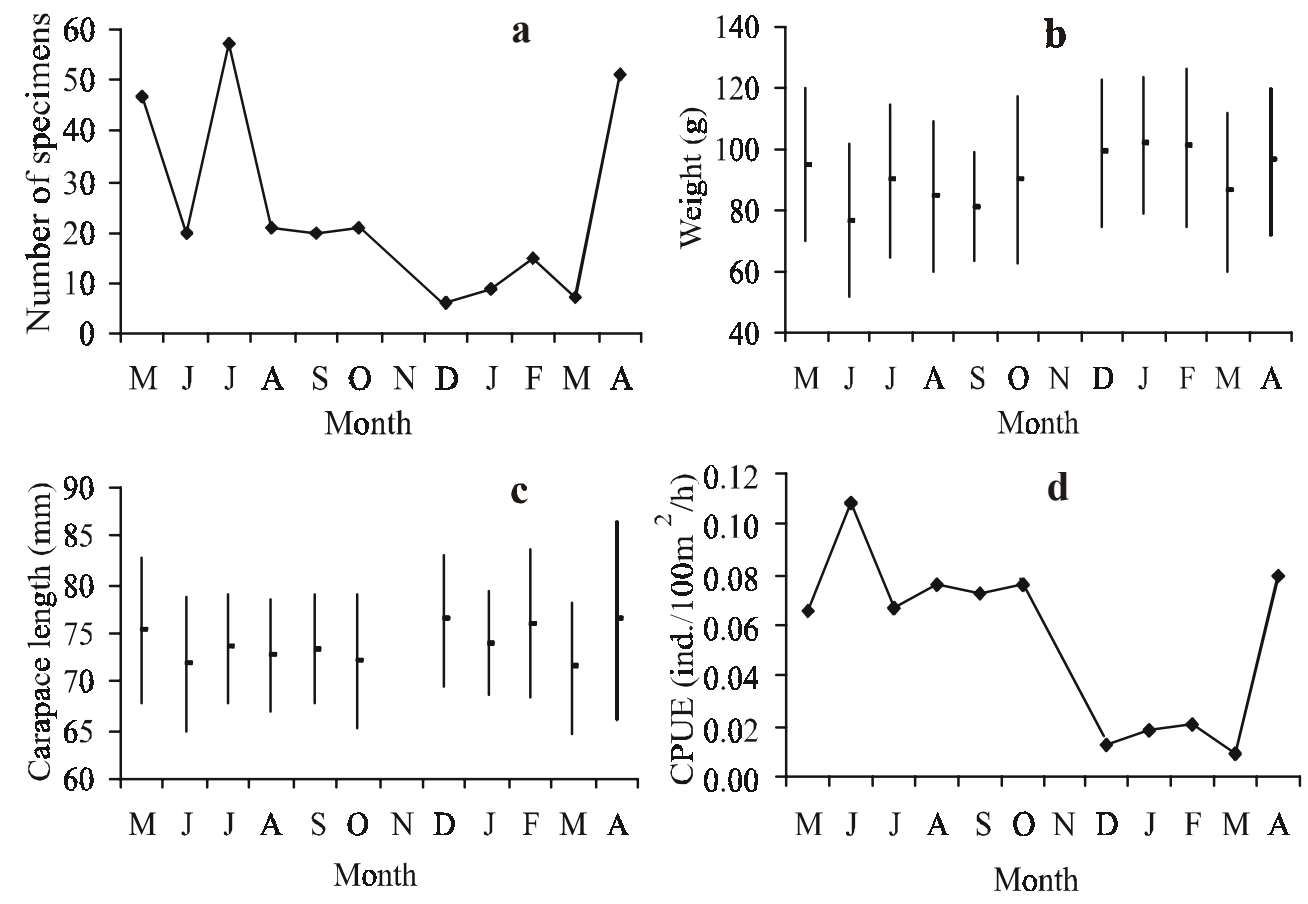

Figure. 2. Catch and measurements of $C$. convexa during this study. (a) Number of specimens, (b) mean fresh weight, (c) mean size (CL, mm), (d) CPUE (ind./100 $\mathrm{m}^{2} / \mathrm{h}$ ).

Figura 2. Captura y medidas de C. convexa en este estudio. (a) Número de especímenes, (b) peso medio en fresco, (c) talla media (CL, mm), (d) CPUE (ind. $/ 100 \mathrm{~m}^{2} / \mathrm{h}$ )

captured varied slightly during the study, with maximum and minimum values registered in April (76.3 mm CL) and June (71.8 mm CL), respectively (fig. 2c). In terms of number of organisms, CPUE was always low (fig. 2d). In terms of weight, the CPUE varied from a minimum of $0.8 \mathrm{~g} / 100 \mathrm{~m}^{2} / \mathrm{h}$ (March) to a maximum of $9.1 \mathrm{~g} / 100 \mathrm{~m}^{2} / \mathrm{h}$ (June) (fig. 3). Crab CPUE (both in weight and number of organisms) reached a maximum value in June, with minimum catches from December through March, and a strong recovery in April (figs. 2d, 3). This monthly variation was significant (ANOVA $P<0.05$ ). In addition, mean CPUE values on rocky, sand and boulder substrates differed significantly $(P<0.05)$ (fig. 4$)$. (tabla 1). En promedio, la captura fue de cerca de 4 especímenes por muestreo. Las diferencias entre capturas por localidad no fueron significativa considerando la frecuencia de muestreo y el número de especímenes obtenidos. No se detectó una segregación espacial por sexo $\left(\chi^{2}>0.05\right)$, pero la comparación de la talla media de los especímenes recolectados indica una diferencia significativa entre las estaciones 8,13 y 14 (prueba de Duncan en $S^{2}, P<0.005$ ).

En total, se dispuso de 274 especímenes (132 machos y 142 hembras) de $C$. convexa. El número de cangrejos obtenidos por mes varió entre 6 y 57 organismos. En noviembre, no hubo captura debido a problemas técnicos (fig. 2a). Considerando todo el material, el peso 


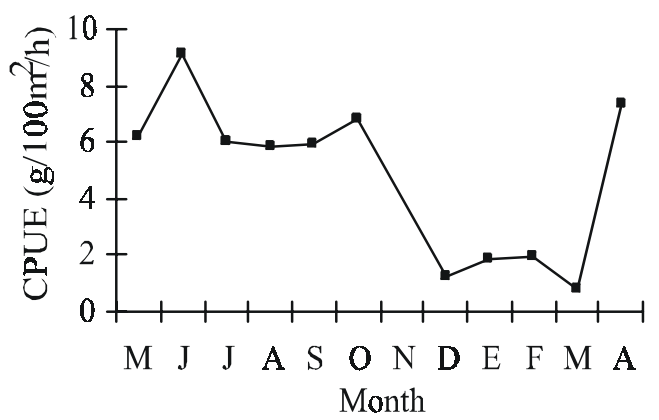

Figure 3. Catch per unit effort $\left(\mathrm{CPUE}, \mathrm{g} / 100 \mathrm{~m}^{2} / \mathrm{h}\right)$ of $C$. convexa during the study, all samples considered.

Figura 3. Captura por unidad de esfuerzo (CPUE; g/ $100 \mathrm{~m}^{2} / \mathrm{h}$ ) de $C$. convexa durante el estudio, considerando todas las muestras.

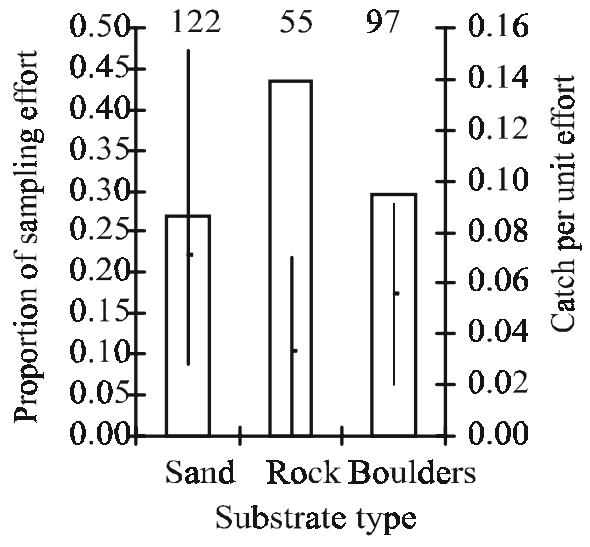

Figure 4. Average sampling effort (CPUE, ind. $/ 100 \mathrm{~m}^{2} / \mathrm{h}$; SD, vertical line) and proportional distribution of effort (rectangles) by type of substrate.

Figura 4. Esfuerzo medio de muestreo (CPUE, ind. $/ 100 \mathrm{~m}^{2} / \mathrm{h}$; SD, línea vertical) y distribución proporcional del esfuerzo (rectángulos) por tipo de sustrato.

\section{Maturity and breeding cycle}

The highest incidence of egg-bearing females was observed in July and August whereas lower values occurred in February, April and May. No ovigerous females were caught the rest of the year (fig. 5). The ovigerous females belonged to the 70 to $90-\mathrm{mm}-\mathrm{CL}$ size classes, where the smallest female with medio por individuo varió de $75.6 \mathrm{~g}$ en junio a $101.4 \mathrm{~g}$ en enero; la talla media por individuo varió de $71.4 \mathrm{~mm}$ en marzo a $76.3 \mathrm{~mm}$ en diciembre (fig. 2b, c). La talla media de los especímenes capturados varió ligeramente durante el estudio, con valores máximos registrados en abril (76.3 mm CL) y valores mínimos en junio (71.8 mm CL) (fig. 2c). En términos de número de organismos, la 


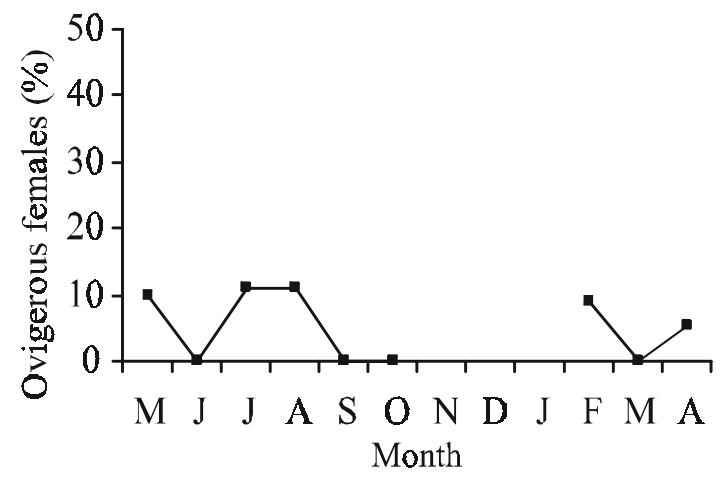

Figure 5. Percentage of ovigerous females of $C$. convexa captured during the study. Figura 5. Porcentaje de hembras ovígeras de C. convexa capturadas durante el estudio.

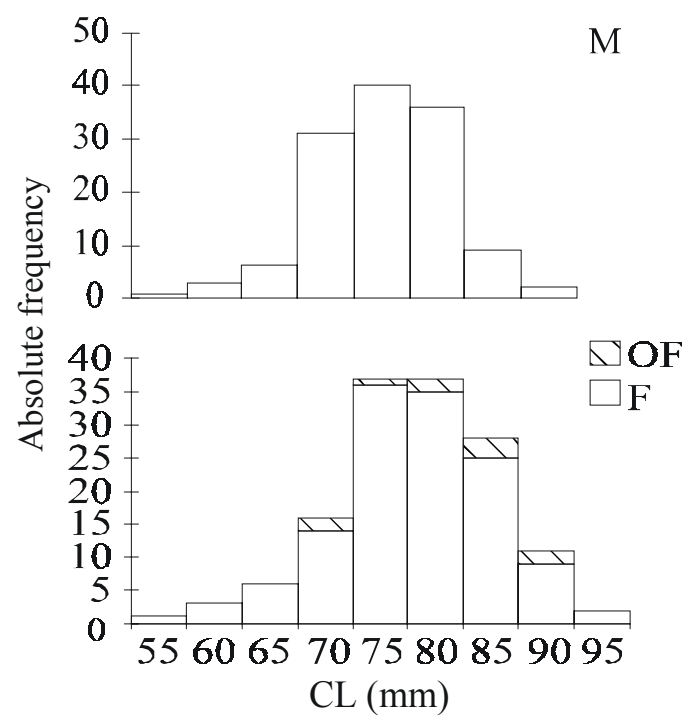

Figure 6. Size-frequency distribution of $C$. convexa during the study, all samples considered. $\mathrm{M}=$ males, $\mathrm{F}=$ females, $\mathrm{OF}=$ ovigerous females.

Figura 6. Distribución de frecuencias de talla de C. convexa durante el estudio, considerando todas las muestras. $\mathrm{M}=$ machos, $\mathrm{F}=$ hembras, $\mathrm{OF}=$ hembras ovígeras. 


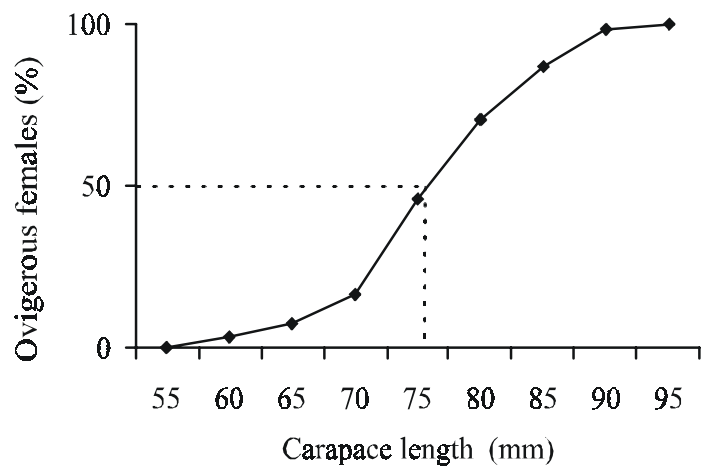

Figure 7. Mean size at first sexual maturity in females of $C$. convexa $(\mathrm{CL}-50)$.

Figura 7. Talla media de primera madurez sexual en hembras de $C$. convexa (CL-50).

eggs was $69.6 \mathrm{~mm}$ CL. The majority of eggbearing females were in the $85-\mathrm{mm}-\mathrm{CL}$ size class (fig. 6). Females reached sexual maturity at a mean size of $75 \mathrm{~mm}$ CL (CL-50) (fig. 7).

The number of eggs per ovigerous female varied from 423,000 (in a 71.2-mm-CL female) to $1,070,000$ (in a $85.5-\mathrm{mm}-\mathrm{CL}$ female). The average number of eggs per specimen $(n=6)$ was 638,885 , with a significant increase in the number of eggs as the organisms were bigger $(r=0.82 ; P<0.05)$.

\section{Population structure}

The distribution of the individual size frequencies was unimodal and not normal in females, and unimodal and normal in males. Overall size interval was slightly wider in females (22.9 $\mathrm{mm}$ to $92.6 \mathrm{~mm} \mathrm{CL})$ than in males (55.0 $\mathrm{mm}$ to $85.8 \mathrm{~mm} \mathrm{CL}$ ) (fig. 6). The average size differed significantly between females (75.7 $\mathrm{mm} \mathrm{CL}$, standard deviation, $\mathrm{SD}=7.3 \mathrm{~mm})$ and males $(72.8 \mathrm{~mm} \mathrm{CL}$, $\mathrm{SD}=5.8 \mathrm{~mm})(P<0.05)$. Modal classes displayed a slight seasonal displacement (spring to winter) towards larger sizes. The widest class interval was observed in spring for both females and males (fig. 8). In both sexes, mean size did not differ significantly from one season to another (spring: $75.9 \mathrm{~mm} \mathrm{CL}$; summer:
CPUE fue siempre baja (fig. 2d). En términos de peso, la CPUE varió de un mínimo de $0.8 \mathrm{~g} / 100 \mathrm{~m}^{2} / \mathrm{h}$ (marzo) a un máximo de $9.1 \mathrm{~g} / 100 \mathrm{~m}^{2} / \mathrm{h}$ (junio) (fig. 3). La CPUE de los cangrejos (tanto en peso como en número de organismos) alcanzó un valor máximo en junio, valores mínimos entre diciembre y marzo, y una fuerte recuperación en abril (figs. 2d, 3). Esta variación mensual fue significativa (ANOVA $P<0.05$ ). Adicionalmente, la CPUE media en substratos rocosos, arenosos $\mathrm{y}$ de cantos rodados difirió considerablemente $(P<0.05)$ (fig. 4).

\section{Madurez y ciclo reproductivo}

La proporción más alta de hembras con huevos se observó en los meses de julio y agosto, mientras que los valores más bajos ocurrieron en febrero, abril y mayo. No se capturaron hembras ovígeras durante el resto del año (fig. 5). Las hembras ovígeras pertenecen a la clase de tallas de 70 a $90 \mathrm{~mm}$ CL. La hembra con huevos más pequeña fue de $69.6 \mathrm{~mm}$ CL. La mayoría de las hembras con huevos se encontraron en las clases de tallas de $85 \mathrm{~mm} \mathrm{CL}$ (fig. 6). Las hembras alcanzaron su madurez sexual a una talla media de $75 \mathrm{~mm} \mathrm{CL}$ (CL-50) (fig. 7).

El número de huevos por hembra ovígera varió entre 423,000 (71.2 $\mathrm{mm}$ CL hembra) y 

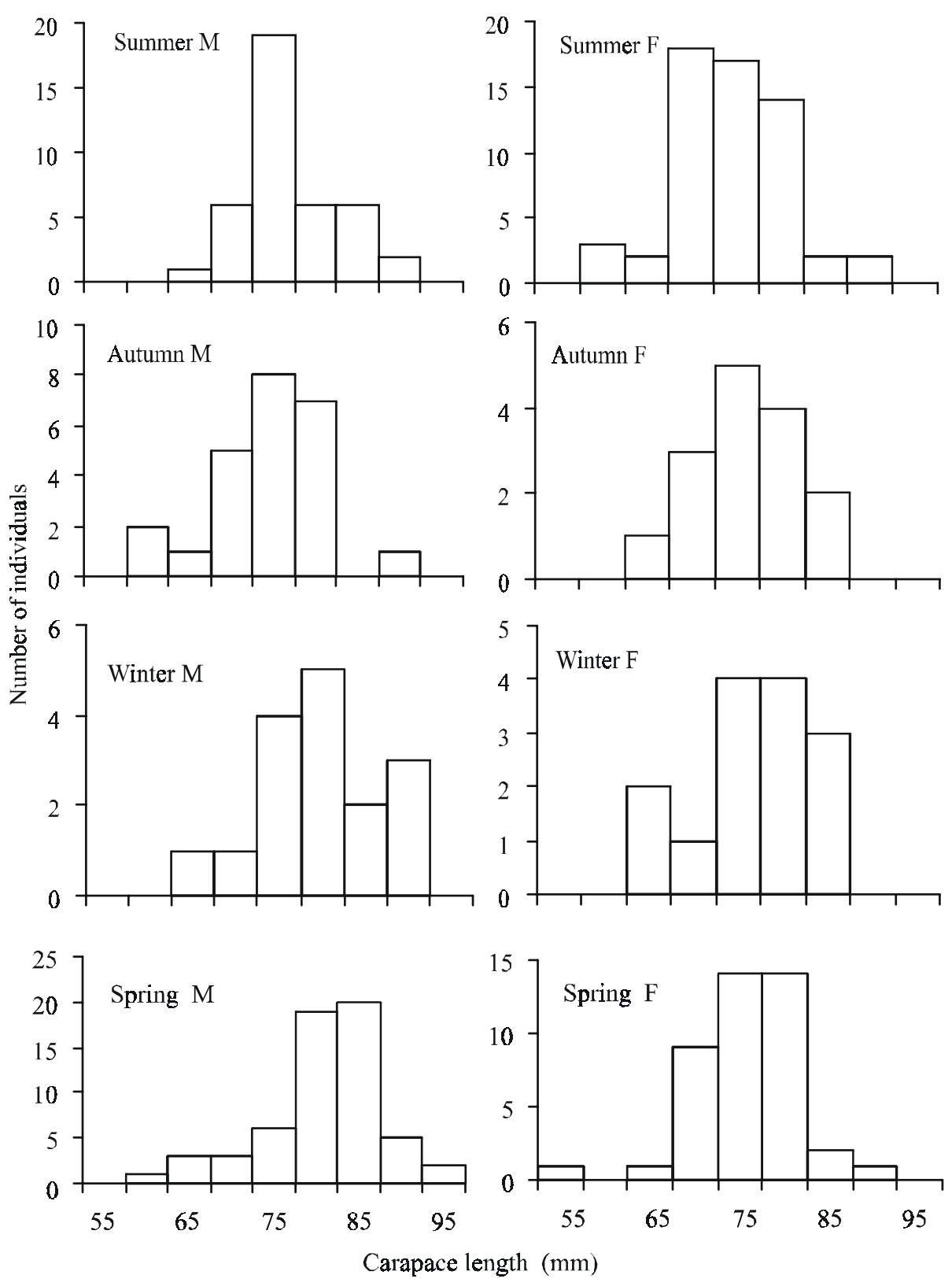

Figure 8. Seasonal size-frequency in $C$. convexa by sex (all samples included). $\mathrm{M}=$ males, $\mathrm{F}=$ females. Figura 8. Frecuencias de talla estacional en C. convexa por sexo (para todas las muestras). $\mathrm{M}=$ machos, $\mathrm{F}=$ hembras. 
Ayón-Parente and Hendrickx: Biology and Fishery of Calappa convexa in the Gulf of California
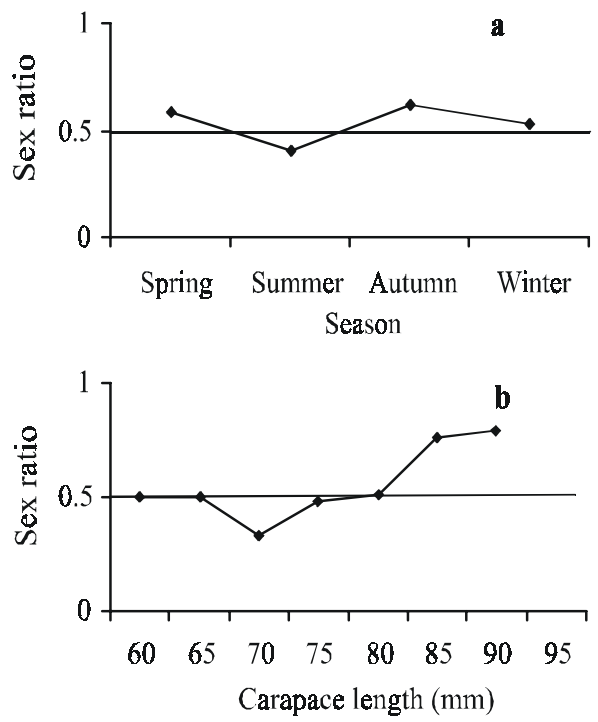

Figure 9. Variation of the F:M ratio by season and size (all samples included).

Figura 9. Variación estacional de la razón F:M, por talla (para todas las muestras).

73.0 mm CL; autumn: $72.8 \mathrm{~mm} \mathrm{CL}$ and winter: $75.5 \mathrm{~mm} \mathrm{CL})(P>0.05)$.

The seasonal F:M ratio varied from 0.41 to 0.61 (fig. 9a), with a greater proportion of females in spring and autumn and, to a lesser extent, in winter. Consequently, the predominance of females in pooled samples was significantly higher $\left(1: 0.92 ; \chi^{2}>0.05\right)$. The sex ratio with respect to size (CL) varied from 0.33 to 0.79 (fig. 9b). Females were clearly dominant in larger sizes ( 85 and $90 \mathrm{~mm} \mathrm{CL}$ ).

\section{Biometric relationships}

Considering all the specimens, the CL:CW ratio was $1: 1.5$. The slope of the $\mathrm{CL}$ :CW relationship in males and the two categories of females (ovigerous and non-ovigerous) did not differ significantly $(t>0.05)$, indicating that the length:width relationship is not significantly different between males and females of C. convexa $\left(r^{2}=0.9301\right)$. Males and females were analyzed separately using a Student's
1,070,000 (85.5 mm CL hembra). El número medio de huevos por espécimen $(n=6)$ fue de 638,885 con un incremento significativo del número de huevos con el crecimiento $(r=0.82$; $P<0.05)$.

\section{Estructura de la población}

La distribución de frecuencias de tallas individuales fue unimodal y no normal en las hembras y unimodal y normal en los machos. El intervalo general de tallas fue ligeramente más amplio en las hembras (22.9 $\mathrm{mm} \mathrm{a}$ $92.6 \mathrm{~mm} \mathrm{CL})$ que en los machos $(55.0 \mathrm{~mm}$ a $85.8 \mathrm{~mm} \mathrm{CL}$ ) (fig. 6). La talla media difirió significativamente entre las hembras (75.7 mm CL; desv. estándar, $\mathrm{SD}=7.3 \mathrm{~mm}$ ) y los machos $(72.8 \mathrm{~mm} \mathrm{CL}, \mathrm{SD}=5.8 \mathrm{~mm})(P<$ $0.05)$. Las clases modales mostraron un ligero desplazamiento por temporada (de primavera a invierno) hacia las tallas más grandes. El intervalo de clases más amplio se observó en 


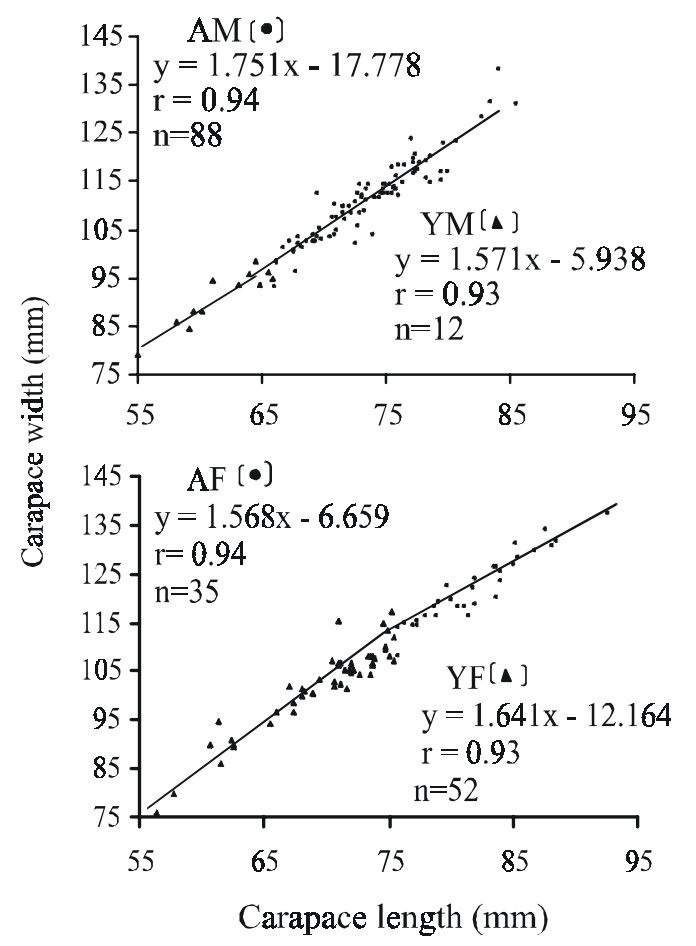

Figure 10. Carapace length:width relationship for adult males (AM), young males (YM), adult females (AF) and young females (YF) of C. convexa.

Figura 10. Relación largo:ancho de caparazón para machos adultos (AM), machos jóvenes (YM), hembras adultas (AF) y hembras jóvenes (YF) de C. convexa.

$t$-test and an inflexion point (a change in the CL:CW slope) was observed for each group (at $65.0 \mathrm{~mm} \mathrm{CL}$ for males and at $73.0 \mathrm{~mm} \mathrm{CL}$ for females). Accordingly, the CL:CW relationships were fitted with two linear regressions (fig. 10) in both sexes. In larger sizes (>75 mm CL), females were narrower while the opposite occurred in males.

Below $60 \mathrm{~mm}$ CL, males generally weighed less than females of the same size (table 2). At larger sizes (> $65 \mathrm{~mm} \mathrm{CL}$ ), the weight of the average male surpassed that of the average female within each size class. In large sizes, the difference between sexes in the size:weight relationship increased as the carapace width increased. The average weight for ovigerous females was greater than that of primavera, tanto para las hembras como para los machos (fig. 8). En ambos sexos, la talla media no difirió significativamente entre una temporada y otra (primavera: $75.9 \mathrm{~mm} \mathrm{CL}$; verano: $73.0 \mathrm{~mm} \mathrm{CL}$; otoño: $72.8 \mathrm{~mm} \mathrm{CL}$; invierno: $75.5 \mathrm{~mm} \mathrm{CL})(P>0.05)$.

La razón $\mathrm{F}: \mathrm{M}$ por temporada varió de 0.41 a 0.61 (fig. 9a), con una proporción más alta de hembras en primavera y otoño, y una menor proporción en invierno. Consecuentemente, la predominancia de hembras en muestras agrupadas fue significativamente más elevada (1:0.92; $\left.\chi^{2}>0.05\right)$. La razón F:M con respecto a la talla (CL) varió de 0.33 a 0.79 (fig. 9b). Las hembras fueron claramente dominantes en las tallas grandes (85 y $90 \mathrm{~mm} \mathrm{CL}$ ). 
Ayón-Parente and Hendrickx: Biology and Fishery of Calappa convexa in the Gulf of California

Table 2. Mean body weight (g) and number of specimens (in brackets) weighted by sex $(\mathrm{M}=$ males, $\mathrm{F}=$ females, $\mathrm{OF}=$ ovigerous females).

Tabla 2. Peso corporal promedio $(\mathrm{g})$ y número de especímenes (entre paréntesis) pesados por sexo (M $=$ machos, $\mathrm{F}=$ hembras, $\mathrm{OF}=$ hembras ovígeras $)$.

\begin{tabular}{cccc}
\hline Size class $(\mathrm{mm})$ & $\mathrm{M}$ & $\mathrm{F}$ & OF \\
\hline $55-60$ & $122.5(4)$ & $132.9(2)$ & - \\
$>60-65$ & $180.5(6)$ & $158.4(6)$ & - \\
$>65-70$ & $198.0(26)$ & $192.3(14)$ & $192.3(2)$ \\
$>70-75$ & $2556.4(35)$ & $243.9(30)$ & $285.9(1)$ \\
$>75-80$ & $291.1(29)$ & $280.8(19)$ & $293.7(2)$ \\
$>80-85$ & $363.6(8)$ & $339.6(11)$ & $353.1(3)$ \\
$>85-90$ & $447.3(2)$ & $410.6(7)$ & $434.8(2)$ \\
$>90-95$ & - & $430(1)$ & - \\
\hline
\end{tabular}

non-ovigerous females of the same size class, mainly due to the weight of the eggs. Considering all specimens, the condition factor varied from $0.110 \times 10^{-2}$ (summer) to $0.230 \times 10^{-2}$ (autumn), while the allometry coefficient varied from 2.70 (autumn) to 2.84 (summer) (fig. 11a). These parameters showed a similar behavior when males and females were considered separately (fig. 11b, c).

In both males and females, there was a linear relationship between the fresh weight of left and right chelipeds and the total fresh weight (fig. 12a, b), with a better fit for males. Some females were accidentally damaged during sampling and lost part of the chelipeds' muscle mass thus accounting for some anomalous values (i.e., chelae fresh weight appears abnormally low). The maximum combined fresh weight of chelipeds was $168.0 \mathrm{~g}(\mathrm{Wt}=486.3 \mathrm{~g})$ for males, and $144.8 \mathrm{~g}(\mathrm{Wt}=459.1 \mathrm{~g})$ for females. The CL:Wp relationship (fig. 12c, d) indicates that the chelae reached a fresh weight of $100 \mathrm{~g}$ in males of about $75.0 \mathrm{~mm} \mathrm{CL}$, while in females, this weight was reached at $79 \mathrm{~mm}$ CL.

\section{Relaciones biométricas}

Considerando todos los especímenes, la razón CL:CW fue 1:1.5. Las pendientes observadas en las relaciones $\mathrm{CL}$ :CW en machos y en cada una de las dos categorías de hembras (ovígeras y no-ovígeras) no difirió significativamente $(t>0.05)$, lo que indica que la relación entre la longitud y el ancho no difiere significativamente entre machos y hembras de $C$. convexa $\left(r^{2}=0.9301\right)$. Los machos y las hembras se analizaron por separado usando una prueba $t$ de Student, observándose un punto de inflexión (un cambio en la pendiente CL:CW) para cada grupo (a $65.0 \mathrm{~mm}$ CL para los machos y a $73.0 \mathrm{~mm}$ CL para las hembras). En consecuencia, la relación $\mathrm{CL}: \mathrm{CW}$ se ajustó a dos regresiones lineales (fig. 10) en ambos sexos. En las tallas mayores ( $>75 \mathrm{~mm} \mathrm{CL}$ ), las hembras fueron más angostas mientras que con los machos sucedió lo opuesto.

Por debajo de la talla $60 \mathrm{~mm} \mathrm{CL}$, los machos generalmente pesaron menos que las hembras de igual tamaño (tabla 2). A mayor tamaño ( $>65 \mathrm{~mm} \mathrm{CL}$ ), el peso de un macho 

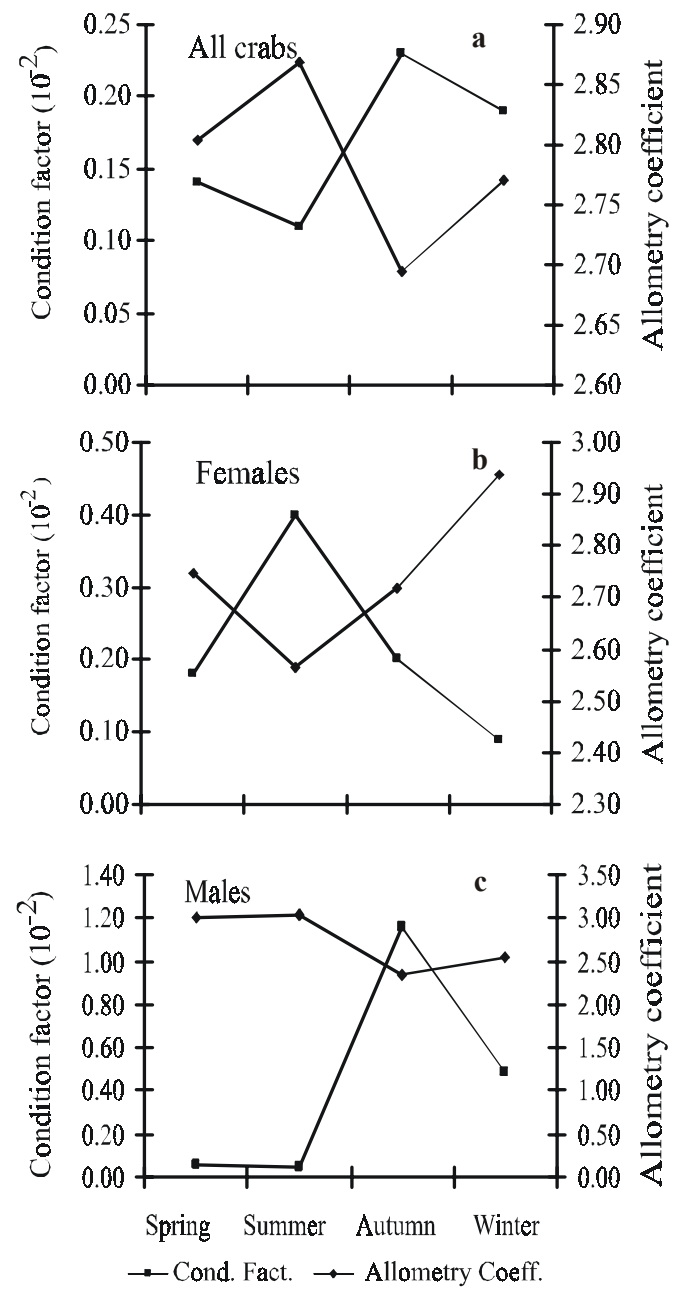

Figure 11. Seasonal variation of the condition factor and the allometry coefficient in C. Convexa. All crabs, females and males.

Figura 11. Variación estacional del factor de condición y del coeficiente de alometría en C. convexa. Todos los cangrejos, hembras y machos.

\section{DISCUSSION}

The arched box crab C. convexa is distributed evenly in shallow water throughout the study area. The data available for deeper water $(>25 \mathrm{~m})$ in the same geographic area indicate that this species occurs along the southern Sinaloa coast from the shore to almost a 40-m medio sobrepasó el de una hembra media dentro de cada clase de talla. En los tamaños mayores, la diferencia entre sexos en la relación talla:peso aumentó conforme aumentaba el ancho del caparazón. El peso medio de las hembras ovígeras fue mayor que el de las demás hembras de la misma clase de talla, en gran parte debido al peso de los huevos. 
depth, but never abundantly (Hendrickx, 1997). The deepest record of this species is from an experimental trawl at 72 to $75 \mathrm{~m}$ in the Gulf of Tehuantepec (Hendrickx et al., 1997). The maximum sizes known, based on material trawled in the Gulf of California and in the Gulf of Tehuantepec, are $134.5 \mathrm{~mm} \mathrm{CW}$ (females) and $144.5 \mathrm{~mm} \quad \mathrm{CW}$ (males) (Hendrickx, 1997).

The seasonal F:M ratio varied from 0.41 to 0.61 . Females were dominant in spring and autumn, and they were also clearly dominant in larger sizes (85- and 90-mm-CL class sizes). Samples obtained during this study indicate that this species reproduces during most of the year but the occurrence of ovigerous females is higher in summer. The smallest egg-bearing female was $69.6 \mathrm{~mm} \mathrm{CL}, 52 \%$ of the largest female size known. No ovigerous females were observed by Hendrickx (1997) in 22 offshore captures between 23 and $75 \mathrm{~m}$, at different times of the year. Surprisingly, the review of all literature dealing with captures of $C$. convexa in the east Pacific reveals just one record of an ovigerous female (Gulf of Tehuantepec; SosaHernández et al., 1980). Even if we accept that authors do not always mention the presence of ovigerous females in their samples, the relative abundance of ovigerous females in shallower coastal waters during this study could indicate that the breeding population occurs near shore.

Stocks accessible to gillnets were low throughout the study. The capture expressed as CPUE (fresh weight) was never higher than $10 \mathrm{~g} / 100 \mathrm{~m}^{2} / \mathrm{h}$. This indicates that a profitable fishery, based on the use of gillnets to catch of C. convexa, is probably not viable, especially considering that only the chelipeds $(30 \%$ of the crab's fresh weight, on average) are harvested by the fishermen. Comparatively, the CPUE of spiny lobsters in the same area using similar nets fluctuates between 4.9 and $60.7 \mathrm{~g} / 100 \mathrm{~m}^{2} / \mathrm{h}$ (Torrescano-Castro and Leyva-Espinoza,
Considerando todos los especímenes, el factor de condición varió entre $0.110 \times 10^{-2}$ (verano) y $0.230 \times 10^{-2}$ (otoño), mientras que el coeficiente de alometría varió de 2.70 (otoño) a 2.84 (verano) (fig. 11a). Estos parámetros mostraron un comportamiento similar cuando machos $\mathrm{y}$ hembras fueron considerados por separado (fig. $11 \mathrm{~b}, \mathrm{c})$.

Tanto en los machos como en las hembras, existe una relación lineal entre el peso en fresco de las quelas izquierda y derecha y el peso en fresco total (fig. 12a, b), con un mejor ajuste para los machos. Algunas hembras se dañaron accidentalmente durante los muestreos y perdieron parte de la masa del músculo de las quelas, lo que generó algunos valores anómalos (i.e., el peso en fresco de la quela aparece anormalmente bajo). El peso fresco combinado de las dos quelas fue de $168.0 \mathrm{~g}(\mathrm{Wt}=486.3 \mathrm{~g})$ para los machos y de $144.8 \mathrm{~g}(\mathrm{Wt}=459.1 \mathrm{~g})$ para las hembras. La relación CL:Wp (fig. 12d, e) indica que las quelas alcanzan un peso fresco de $100 \mathrm{~g}$ en machos de cerca de $75.0 \mathrm{~mm} \mathrm{CL}$, mientras que en las hembras, este peso es alcanzado a los $79 \mathrm{~mm}$ CL.

\section{DISCUSIÓN}

El cangrejo cajeta bola, C. convexa, se encuentra distribuido de manera uniforme en las aguas someras del área estudiada. La información disponible para aguas más profundas $(>25 \mathrm{~m})$ para la misma área geográfica indica que esta especie se encuentra a lo largo de la costa del sur de Sinaloa, desde la orilla hasta casi $40 \mathrm{~m}$ de profundidad, pero nunca de manera abundante (Hendrickx, 1997). El registro más profundo se ha obtenido en el Golfo de Tehuantepec, en un arrastre experimental entre los $72 \mathrm{y}$ los $75 \mathrm{~m}$ de profundidad (Hendrickx et al., 1997). Las tallas máximas conocidas, en base a material recolectado en el Golfo de California y en el Golfo de Tehuantepec son 

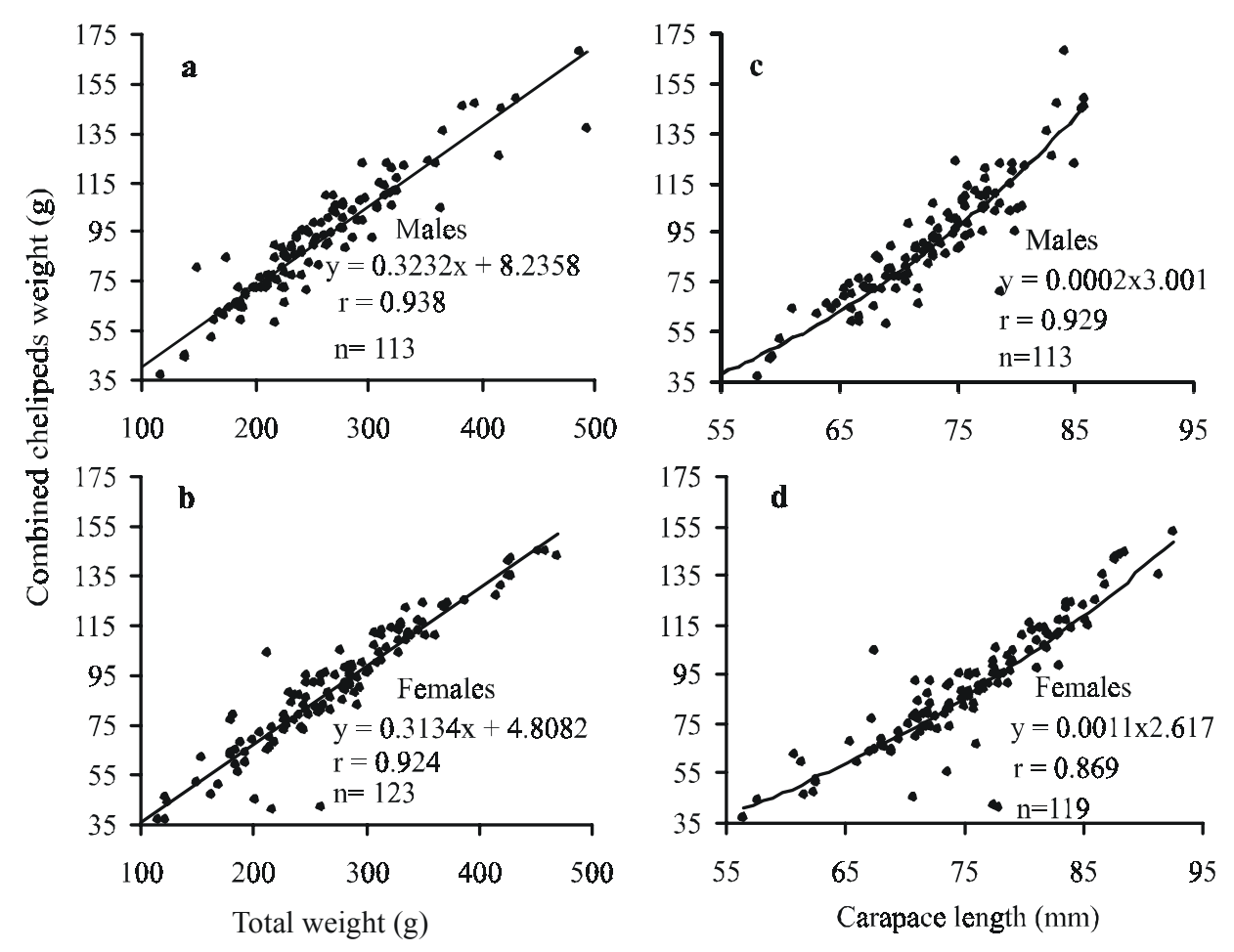

Figure 12. Chelipeds fresh weight $(\mathrm{g}) v s$.total weight $(\mathrm{g})$ and carapace length $(\mathrm{mm})$ in $C$. convexa, by sex. Figura 12. Peso en fresco de quelípedos ( $\mathrm{g})$ vs. peso total $(\mathrm{g})$ y largo de caparazón $(\mathrm{mm})$ en C. convexa, por sexo.

1996). The maximum combined fresh weight of left and right chelipeds in adults showed interesting values. Considering the maximum size reached by the species, the maximum fresh weight values expected for both chelipeds together would be in the range of 100 to $170 \mathrm{~g}$.

The data obtained in shallow coastal water (this study) and the literature available for offshore localities (inner and mid-shelf) show that the abundance of $C$. convexa is low. The maximum catch reported by Hendrickx (1997) in 35' commercial shrimp otter-trawls was in the range of 1 to 4 specimens per hour of trawling. The CPUE in gillnets was never higher than $0.11 \mathrm{ind} . / 100 \mathrm{~m}^{2} / \mathrm{h}$. A specific sustainable fishery in shallow coastal waters would require a
$134.5 \mathrm{~mm} \mathrm{CW}$ (hembras) y $144.5 \mathrm{~mm} \mathrm{CW}$ (machos) (Hendrickx, 1997).

Los valores estacionales de la razón F:M indican una variación entre 0.41 y 0.61 . Las hembras predominaron en primavera y verano, y también fueron claramente dominantes en las tallas mayores (clases de tallas de 85 y $90 \mathrm{~mm}$ CL). Las muestras obtenidas en este estudio indican que la especie se reproduce durante la mayor parte del año pero que la ocurrencia de hembras ovígeras es más alta en verano. La hembra ovígera más pequeña midió $69.6 \mathrm{~mm}$ CL, $52 \%$ de la talla máxima conocida para las hembras. Hendrickx (1997) no observó hembras ovígeras en las 22 capturas costeras realizadas entre 23 y 75 m, en diferentes épocas del 
minimum catch per day of 120 to 200 adult sized crabs (i.e., $\mathrm{CL}>75 \mathrm{~mm}$ ) to produce a total fresh weight of at least $12 \mathrm{~kg}$ of claws. Considering local market prices for similar seafood (swimming crabs of the genus Callinectes), fresh claws from $C$. convexa could attain 3 to 4 US dollars per kg. Other species currently exploited from lobster by-catch are the stone crab Menippe frontalis A. Milne Edwards, 1879; mollusks such as Hexaplex nigritus (Philippi, 1845) and Phyllonotus erythrostoma (Swainson, 1831); and yellow and colorado snappers, Lutjanus argentiventris (Peters, 1869) and L. colorado Jordan and Gilbert, 1882, respectively (Perez-González et al., 1994; Hendrickx, 1995a). Clearly, ancillary harvesting of $C$. convexa represents a potentially additional income for fishermen dedicated to the lobster fishery in the area.

\section{ACKNOWLEDGEMENTS}

The authors wish to thank Mercedes Cordero R. for the editorial work on this manuscript.

\section{REFERENCES}

Ayón-Parente, M. (1997). Crustáceos decápodos asociados a la captura de la langosta Panulirus spp. (White, 1847) en el sur de Sinaloa. Tesis de Licenciatura. Univ. Autón. Sinaloa. Fac. Cienc. Mar. $92 \mathrm{p}$.

Caldwell, M.A. (1992). Aspects of the biology of the stone crab, Menippe mercenaria (Say), from South Carolina, with comments on the South Carolina stone crab fishery. pp: 99-106. In: T.M. Bert (Ed.). Proceedings of a symposium on the stone crab (genus Menippe) biology and fisheries. State of Florida: Florida Mar. Res. Inst. Publ. 50: $118 \mathrm{p}$.

Garth, J.S. (1946). Littoral brachyuran fauna of the Galapagos. Brachyura. Allan Hancock Pac. Exped. 5 (10): 341-601. año. Sorprendentemente, la revisión de la literatura que trata acerca de las capturas de $C$. convexa en el Pacífico oriental revela solo un registro de una hembra ovígera (Golfo de Tehuantepec; Sosa-Hernández et al., 1980). Aún si se admite que los autores no siempre mencionan la presencia de hembras ovígeras en sus muestras, la abundancia relativa de hembras ovígeras en aguas costeras someras durante este estudio podría indicar que la reproducción de la población ocurre cerca de la costa.

Las capturas accesibles a las redes de enmalle durante todo el estudio fueron bajas. La captura, expresada en CPUE (peso en fresco), nunca fue mayor a los $10 \mathrm{~g} / 100 \mathrm{~m}^{2} / \mathrm{h}$. Esto indica que el beneficio de una pesquería basado en el uso de redes de enmalle para capturar $C$. convexa probablemente no es viable, especialmente si se considera que solo las quelas (en promedio el 30\% del peso en fresco del cangrejo) son conservadas por el pescador. Comparativamente, la CPUE de las langostas espinosas en la misma área, usando redes similares, fluctúa entre 4.9 y $60.7 \mathrm{~g} / 100 \mathrm{~m}^{2} / \mathrm{h}$ (Torrescano-Castro y Leyva-Espinoza, 1996). El máximo peso fresco combinado de las quelas izquierda y derecha mostró valores interesantes en los adultos. Considerando la talla máxima alcanzada por la especie, los valores máximos del peso en fresco esperados para ambas quelas estarían en el intervalo de 100 a $170 \mathrm{~g}$.

La información obtenida en aguas costeras (este estudio) y la literatura disponible para la plataforma continental (partes interior e intermedia) muestran que la abundancia de $C$. convexa es baja. La captura máxima reportada por Hendrickx (1997) para los arrastres con redes comerciales camaroneras de $35^{\prime}$ fue de 1 a 4 especímenes por hora de arrastre. La CPUE en redes de enmalle nunca fue mayor 
Garth, J.S. (1948). The Brachyura of the Askoy Expedition with remarks on carcinological collecting in the Panama Bight. Bull. Amer. Mus. Nat. Hist. 92 (1): 1-66.

Garth, J.S. (1966). Eastern Pacific Expeditions of the New York Zoological Society. XLVI. Oxystomatous and allied crabs from the west coast of tropical America. Zool. 51: 1-16.

Hatcher, B.G., Johannes, R.E. and Robertson, A.I. (1989). Review of research relevant to the conservation of shallow tropical marine ecosystems. Oceanogr. Mar. Biol. Annu. Rev. 27: 337-414.

Hebling, N.J., Mantelatto, F.L., Negreiros-Fransozo, M.L. and Fransozo, A. (1994). Levantamento e distribuiçao de Braquiúros e Anomuros (Crustacea, Decapoda) dos sedimentos sublitorais da regiao da Ilha Anchieta, Ubatuba (SP). Bol. Inst. Pesca. 21: 1-9.

Hendrickx, M.E. (1985). Diversidad de los macroinvertebrados bentónicos acompañantes del camarón en el área del Golfo de California y su importancia como recurso potencial. In: Yáñez-Arancibia, A. (Ed.). Recursos Pesqueros Potenciales de México. La Pesca Acompañante del Camarón, p. 95-148. Prog. Univ. Aliment. Inst. Cienc. Mar y Limnol. Inst. Nal. Pesca, UNAM, México, 784 p.

Hendrickx, M.E. (1993). Crustáceos decápodos bentónicos del sur de Sinaloa, México. An. Inst. Biol. Univ. Nal. Autón. México. Ser. Zool. 64(1): 1-16.

Hendrickx, M.E. (1995a). Cangrejos. In: Guía FAO para la Identificación de Especies para los Fines de la Pesca. Pacífico Centro-oriental. Vol. I. Plantas e Invertebrados, p. 565-636. W. Fischer, F, Krupp, W. Schneider, C. Sommer, K.E. Carpenter y V.H. Niem (Eds). F.A.O. Roma, Italia. $646 \mathrm{p}$.

Hendrickx, M.E. (1995b). Checklist of brachyuran crabs (Crustacea: Decapoda) from the Eastern Tropical Pacific. Bull. Inst. Roy. Sci. Nat. Belgique. 65: 125-150.

Hendrickx, M..E. (1996). Habitats and biodiversity of decapod crustaceans in the SE Gulf of California, Mexico. Rev. Biol. Trop. 44 (2A): 603-617.

Hendrickx, M.E. (1997). Los cangrejos braquiuros (Crustacea: Brachyura: Dromiidae, hasta que 0.11 ind. $/ 100 \mathrm{~m}^{2} / \mathrm{h}$. Una pesquería sustentable en aguas costeras someras requeriría una captura mínima diaria de 120 a 200 cangrejos de talla adulta (i.e., $\mathrm{CL}>75 \mathrm{~mm}$ ) para alcanzar un peso en fresco total de, al menos, $12 \mathrm{~kg}$ de quelas. Considerando los precios del mercado local para mariscos similares (cangrejos del género Callinectes), las quelas frescas de $C$. convexa prodrían alcanzar un precio entre 3 y 4 dólares de los EUA por kg. Otras especies de la fauna de acompañamiento de la langosta actualmente explotadas incluyen el cangrejo de piedra estridulante Menippe frontalis A. Milne Edwards, 1879; los moluscos Hexaplex nigrinstus (Philippi, 1845) y Phyllonotus erythrostoma (Swainson, 1831); y los pargos amarillo y colorado, Lutjanus argentiventris (Peters, 1869) y L. colorado Jordan y Gilbert, 1882 (Perez-González et al., 1994; Hendrickx, 1995a). Evidentemente, la captura incidental de C. convexa representa solamente un ingreso potencial adicional para los pescadores dedicados a la pesca de la langosta en el área.

\section{AGRADECIMIENTOS}

Los autores agradecen a Mercedes Cordero R. por el trabajo editorial realizado con este manuscrito.

Traducido al español por los autores.

Leucosiidae) del Pacífico mexicano. Comisión Nacional para el Conocimiento y Uso de la Biodiversidad e Inst. Cienc. Mar y Limnol., UNAM, México. 178 p.

Hendrickx, M.E. and Ayón-Parente, M. (1996). Composition and abundance of decapod in the lobster by-catch, SE Gulf of California, Mexico, 1996. In: Aquaculture and Fisheries, p. 106. 2nd European Crustacean Conference - Liege, Belgium. September 2-6, 1996. 
Ayón-Parente and Hendrickx: Biology and Fishery of Calappa convexa in the Gulf of California

Hendrickx, M.E., Demestre, M., Esparza-Haro, A. and Salgado-Barragán, J. (1997). Stomatopod and decapod crustaceans collected during the CEEMEX P5 and P7 cruises to the Gulf of Tehuantepec, Mexico. Oceanides. 11(2): 1-28.

Lim-Cisneros, M.A. y Chavira-Oropeza, M.A. (1995). Crustáceos decápodos asociados a la pesca de la langosta en el sur de Sinaloa. Tesis de Licenciatura. Univ. Autón. Sinaloa. Fac. Cienc. Mar. 65 p.

McNeely, J.A., Miller, K.R., Reid, W.V., Mittermeier, R.A. and Werner T.B. (1990). The information required to conserve biological diversity. In: Conserving the World's Biological Diversity, p. 71-81. VIUCN, WRI, CI, WWFUS, The World Bank.

Medina-Mantelatto, F.L. and Petracco, M. (1997). Natural diet of the crab Hepatus pudibundus (Brachyura: Calappidae) in Fortaleza Bay, Ubatuba (SP), Brazil. J. Crust. Biol. 17 (3): 440446.

Motoh, H. (1997). Edible crustaceans of Ecuador, South America - I. Crabs. Bull. Niigata Pref. Biol. Soc. Educ. 32: 47-53.

Pérez-González, R., Flores-Campaña, L.M., Borrego, M.I. y Valadez-Manzano, L.M. (1994). Fauna asociada a la pesca de la langosta durante la época fria, en el sur de Sinaloa. Ciencias del Mar, Epoca 1, 13: 21-26.

Rathbun, M.J. (1937). The oxystomatous and allied crabs of America. U.S. Natl. Mus. Bull. 166: 1278.

Reigada, A.L.D., Negreiros-Fransozo, M.L. and Medina-Mantelatto, F.L. (1994). Appraisal of the cheliped's size on Hepatus pudibundus (Herbst, 1785) (Crustacea, Calappidae) in function of sex and maturation. Arq. Biol. Tecnol. 37 (4): 797-807.

Ricker, E.H. (1975). Computation and interpretation of biological statistics of fish populations. Bull. Fish. Res. Bd. Canada. 191: 382.

Rodríguez de la Cruz, M.C. (1987). Crustáceos Decápodos del Golfo de California. Sría. Pesca (Ed), México, D.F. 306 p.

Sosa-Hernández, P., Hernández-Aguilera, J.L. y Villalobos-Hiriart, J.L. (1980). Estudio prospectivo de los crustáceos (Decapoda y Stomatopoda) del Golfo de Tehuantepec, México. Secretaría de Marina, Dirección General de Oceanografía. Inv. Ocean. 1-50.

Thorpe, J., Gall, G., Lannan, J. and Nash, C. (1995). Conservation of Fish and Shellfish Resources: Managing Diversity. Academic Press. 206 p.

Torrescano-Castro, C.G. y Leyva-Espinoza, H. (1996). Eficiencia en redes de enmalle y nasas para la pesca de langosta Panulirus (White, 1847), en el sur de Sinaloa, México. Tesis de Licenciatura. Univ. Autón. Sinaloa. Fac. Cienc. Mar. $65 \mathrm{p}$.

UNEP. (1997). Convention on biological diversity. UNEP/CBD/JM/Expert/1/5 Report. Jakarta Mandate on Marine and Coastal Biological Diversity. 39 p.

Von Prahl, H. y Sánchez, O.F. (1986). Cangrejos calápidos (Crustacea: Brachyura: Calappidae) del Pacífico Colombiano. Bol. Ecotrópica. 14: 21-33. 